\title{
Structural And Earthquake Evaluations Along Java Subduction Zone, Indonesia
}

\author{
Adi Patria ${ }^{1^{*}}$, Atin Nur Aulia ${ }^{1}$ \\ ${ }^{1}$ Pusat Penelitian Geoteknologi LIPI
}

\begin{abstract}
Java Subduction is a zone of trench perpendicular convergence of Australian Plate and Southeast Asia in the south of Java. It is characterized by an almost E-W trending trench with an eastward increase of convergence velocity. Three major earthquakes with tsunamis have been caused by deformation along this subduction zone. Although many studies have undertaken to understand the nature of the subduction system, a clear relationship between structures and earthquake activities remains poorly explained. In this study, we used bathymetry, residual bathymetry, and published seismic reflection profiles to evaluate structural and morphological elements, then link the observations to earthquake activity along Java Subduction Zone. Based on seafloor morphology, characteristics of the accretionary wedge and forearc basin varies along the trench in response to the variation of seafloor morphology. Features such as seamounts and ridges which were observed in the oceanic basin may be subducted beneath accretionary wedge and disrupt the morphology of accretionary wedge, forearc basin, and trench. Earthquake activities are generally dominated by normal fault solutions in the trench, which is attributed to plate bending faults while thrust fault solution is observed in the forearc basin area. Thrust fault activities in accretionary
\end{abstract}

Naskah masuk : 25 September 2019

Naskah direvisi : 25 November 2019

Naskah diterima : 11 Desember 2019

* Corresponding Author.

Email : adi.patria21@gmail.com wedge are decreased to the east, where there is no thrust fault solution observed in the eastern end of the subduction zone. Few strike-slip focal mechanisms are observed and mainly located within the subducting oceanic plate. Structures and subducting oceanic features may control the earthquake activity where deformation occurred at the edge of these features. The two largest thrust fault earthquakes in 1994 and 2006 are interpreted as a result of deformation along with plate interface on soft or unconsolidated sediment above the incoming plate. The largest normal fault earthquake with a magnitude of 8.3 is possibly caused by a crustal scale-fault that breaks the entire oceanic crust.

Keywords: Subduction Zone, Bathymetry, Earthquake, Geological Structures, Indonesia.

ABSTRAK Evaluasi struktur dan gempa bumi di sepanjang zona subduksi jawa, indonesia. Subduksi Jawa adalah zona konvergensi yang tegak lurus palung antara Lempeng Australia dan Asia Tenggara di selatan Jawa. Hal ini ditandai dengan palung berarah hampir barat-timur dengan peningkatan kecepatan konvergensi ke arah timur. Tiga gempa bumi besar dengan tsunami disebabkan oleh deformasi di sepanjang zona subduksi ini. Meskipun banyak penelitian telah dilakukan untuk memahami sifat sistem subduksi, hubungan antara struktur dan kegiatan gempa bumi masih kurang jelas. Dalam studi ini, kami menggunakan batimetri, batimetri residual, dan profil refleksi seismik untuk mengevaluasi elemen struktur dan morfologi, kemudian menghubungkan pengamatan dengan aktivitas gempa bumi di sepanjang zona subduksi Jawa. Berdasarkan morfologi dasar laut, karakteristik prisma akresi dan cekungan busur muka bervariasi di sepanjang palung sebagai respon terhadap variasi morfologi dasar laut. Fitur seperti seamount dan punggungan yang diamati di cekungan samudera menunjam di bawah prisma akresi dan mengganggu morfologi prisma akresi, 
cekungan busur muka, dan palung. Aktivitas gempa bumi umumnya didominasi oleh patahan normal di palung, yang dikaitkan dengan patahan tekukan lempeng sedangkan patahan naik diamati di daerah cekungan busur muka. Aktivitas sesar naik di dalam prisma akresi berkurang ke arah timur, di mana tidak ada patahan naik yang teramati di ujung timur zona subduksi. Beberapa mekanisme patahan mendatar diamati dan terutama terletak di dalam lempeng samudera yang menunjam. Struktur dan fitur di kerak samudra yang menunjam dapat mengontrol aktivitas gempa bumi di mana deformasi terjadi di tepian fitur ini. Dua gempa bumi besar dengan sifat patahan naik pada tahun 1994 dan 2006 ditafsirkan sebagai hasil dari deformasi di sepanjang antarmuka lempeng pada sedimen lunak atau tidak terkonsolidasi di atas lempeng yang masuk. Gempa bumi besar akibat sesar normal dengan magnitudo 8,3 mungkin disebabkan oleh patahan skala-kerak yang menghancurkan seluruh kerak samudera.

Kata kunci: Zona Subduksi, Batimetri, Gempa Bumi, Struktur Geologi, Indonesia.

\section{INTRODUCTION}

Sunda Subduction Zone, which elongates from the Andaman Sea to the south of Lesser Sunda along $7000 \mathrm{~km}$, is an active convergent margin resulting from subduction of Oceanic Australian Plate beneath Southeast Asia (Hamilton 1979). Java Subduction Zone as part of Sunda Subduction in the east is located in the south of Java and commonly considered as a classic example of orthogonal subduction system. It has been active since Paleogene (Hamilton 1979; Hall 2012) and now converge with velocity around $70 \mathrm{~mm} / \mathrm{yr}$ (Simons et al. 2007; DeMets et al. 2010). It has significant along-trench variabilities in trench depth, orientation, convergence velocity, seafloor morphology, and seismicity. It also has contributed to earthquake activities along the south of Java in some of which have caused tsunamis that hit south Java coast. At least three significant and instrumentally-recorded earthquakes with the tsunami have been generated along Java Subduction Zone (Figure 1). The Mw 8.31977 Earthquake in the south of Sumba was caused by outer-rise deformation (Lynnes and Lay 1988) with an $8 \mathrm{~m}$ maximum tsunami run-up. The Mw 7.8 1994 Earthquake in the south of East Java has produced a tsunami with run-up around
$13 \mathrm{~m}$ and caused more than 200 casualties (Tsuji et al. 1995). Then the Mw 7.72006 Earthquake was occurred in the south of West Java and followed by a tsunami with around $8 \mathrm{~m}$ average run-up, which has caused more than 600 deaths (Fritz et al. 2007).

Structures along Java Subduction Zone has mainly been studied using seismic refraction, seismic reflection and high-resolution bathymetry to reveal structural elements and their earthquake hazards (e.g. Malod et al. 1995; Kopp et al. 2002; Kopp and Kukowski 2003; Susilohadi et al. 2005; Kopp et al. 2009; Krabbenhoeft et al. 2010; Planert et al. 2010; Lüschen et al. 2011; Shulgin et al. 2011). Although the results from studies were successfully mapped the plate structures, geological structures, morphology, and many tectonic features both on the oceanic and overriding plate, there was little attention to the link between observed structures and earthquake activities along this margin and its surrounding. Previous studies were mainly concerned with the deformation of the megathrust or plate interface, but the nature of other parts of the subduction zone remains problematical. Using combined analysis of Indonesian Bathymetry Data (BATNAS), residual bathymetry data (from Bassett \& Watts, 2015) and earthquake catalogue (ISC-EHB and Global CMT) with as well as previous result from many authors (i.e. Kopp et al. 2009; Planert et al. 2010; Lüschen et al. 2011; Shulgin et al. 2011) is expected to give a chance in assessing different hypotheses. This study presents interpretations of bathymetric data and seismicity around the region combined with published data from several authors, in order to characterize the structure of both upper and lower plates and to investigate their roles and interactions on controlling occurrences of the earthquake.

\section{GEOLOGIC SETTING}

Java Trench marks the southern end boundary of convergence between the Australian Plate and Southeast Asia (Figure 1). The Australian plate moves toward the northeast and is relatively perpendicular to Java Trench with the velocity with eastward increase of velocity from $68 \mathrm{~mm} / \mathrm{yr}$ to $73 \mathrm{~mm} / \mathrm{yr}$ (DeMets et al. 2010). The deformation along Java Subduction region is mainly accommodated by thrust faults (e.g. Kopp et al. 2002; Kopp and Kukowski 2003; Kopp et al. 2009; Planert et al. 2010; Lüschen et al. 2011; 
Shulgin et al. 2011), different to oblique Sumatra Subduction Zone which is characterized by combination of thrust faults and strike-slip faults (e.g. Sieh and Natawidjaja 2000; Henstock et al. 2006; Natawidjaja and Triyoso 2007; Singh et al. 2008; McCaffrey 2009; Chauhan et al. 2009; Singh et al. 2011; Mukti et al. 2012; Daryono et al. 2012; Henstock et al. 2018).

Based on seafloor morphology, the Oceanic Australian Crust consists of three major morphological features: Christmas Island Seamount Province, Roo Rise, and Argo Abyssal Plain (Figure 1). The Christmas Island Seamount Province is a series of elevated seamount morphologies, rising about $2-5 \mathrm{~km}$ from the surrounding in which exposed on land, forming Christmas Island. The Roo Rice is a large plateau, elevated more than $1.5 \mathrm{~km}$ above the adjacent seafloor with $400 \mathrm{~km}$ length in the axis. It is believed that the subduction of seamounts and Roo Rise beneath accretionary wedge has contributed to landward trench progression and to an abrupt change of morphology of accretionary wedge (Masson et al. 1990; Kopp et al. 2006). These oceanic structures were also considered to play a role as either asperity or barrier for the earthquake. The Mw 7.81994 Earthquake is interpreted to slip over subducting seamount (Abercrombie et al. 2001; Bilek and Engdahl 2007) or plateau (Bassett and Watts 2015) while the deformation of $\mathrm{Mw} 7.7$ 2006 Earthquake was limited by subducting seamount in the east of hypocentre (Bilek and Engdahl 2007; Bassett and Watts 2015). Argo Abyssal Plain is a relatively smooth and low relief morphology on Indo-Australian Oceanic Crust in the south of Lesser Sunda. The age of oceanic crust in Java Subduction Zone becomes younger to the west from Late Jurassic in Argo Abyssal Plain to Early Cretaceous in the south of West Java, Christmas Island with NE-SW trending age lineament (Heine et al. 2004).

The Java Subduction Zone consists of a trench, an accretionary wedge, and forearc basins. The trench shows variation in direction and depth. The

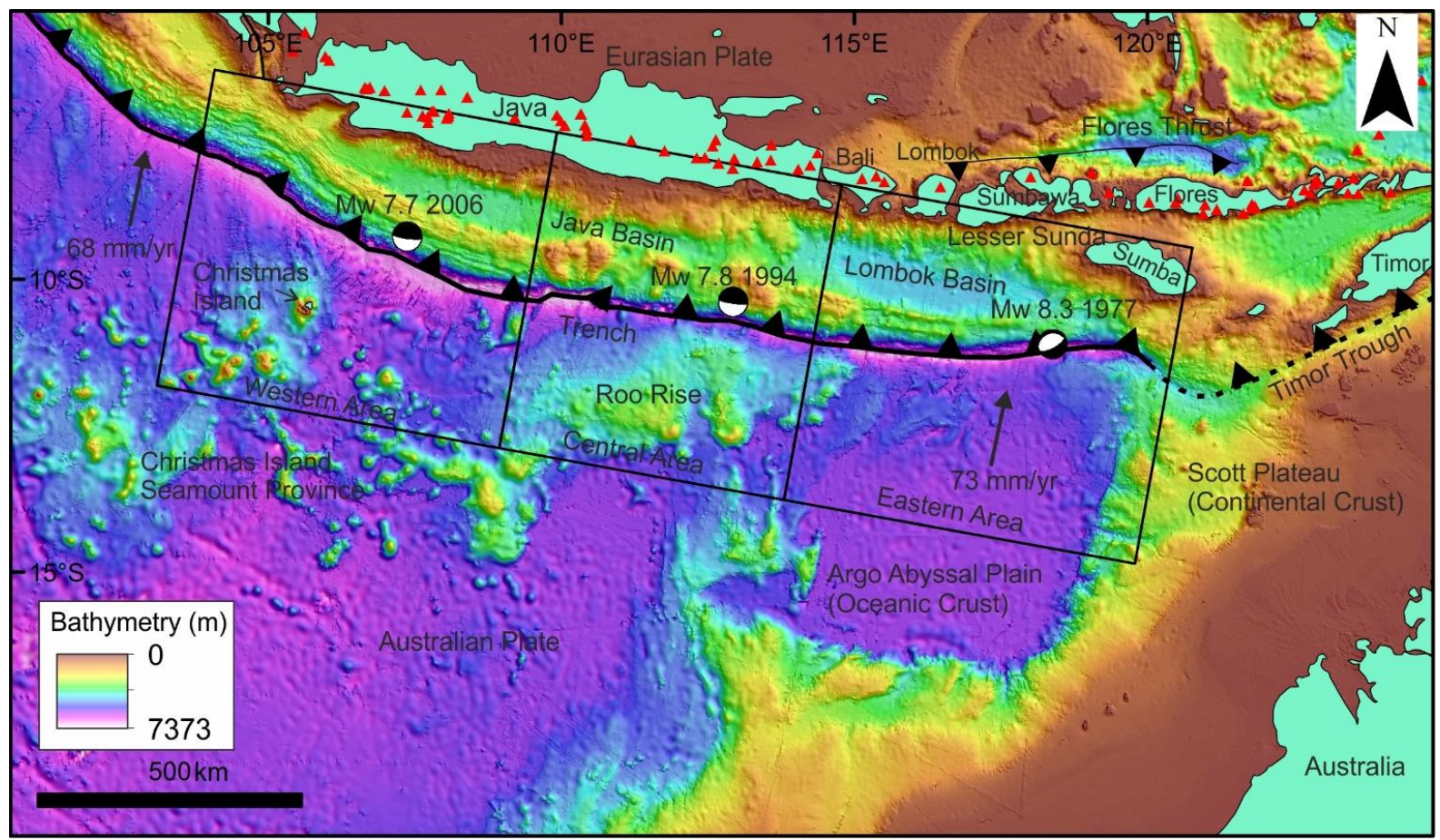

Figure 1. Tectonic elements and main morphological features of Java Subduction Zone. Subduction Zone is indicated by toothed bold solid black lines. The surface expression of Banda Subduction is marked by toothed dashed black lines. Red triangles denote volcanos. Focal Mechanism Solution of three notable earthquake Mw $\geq 7$ (from Global CMT Catalogue). Plate motion vector and velocity are according to Global Velocity Model MORVEL (DeMets et al. 2010). Bathymetry is from Indonesian Bathymetric Data (BATNAS). 
direction changes from NW-SE in the south of West Java to N-E in the south of Lesser Sunda, and the depth is more than $6000 \mathrm{~m}$. The trench is in places deflected to the north in the response of the subduction of seamounts and Roo Rise, and it is shallower where the trench is in contact with seamounts and Roo Rise (Kopp et al. 2006). Near trench, the area is dominated by abundant normal faults formed due to the plate bending of the subducting plate (Masson et al. 1990; Kopp et al. 2006; Lüschen et al. 2011). The accretionary wedge consists of the imbrication of landwarddipping thrust faults in which detached on plate interface (Kopp et al. 2009; Lüschen et al. 2011; Nugraha and Hall 2012). The slope break of the accretionary wedge is interpreted as the up-dip limit of the seismogenic zone, while the landward limit of accretionary wedge marks the downdip boundary of the seismogenic zone in Java Subduction Zone (Krabbenhoeft et al. 2010). The forearc basin is divided into Java Basin and Lombok Basin. The depth of Lombok Basin reaches more than $4200 \mathrm{~m}$, deeper than Java Basin, which is around $3600 \mathrm{~m}$. It goes narrow to the east and limited by Sumba in the west. A wrench fault is observed at the eastern boundary of Lombok Basin and interpreted as a zone of transition from the subduction system to the collision regime (Lüschen et al. 2011).

Seismicity in Java Subduction Zone is characterized by the absence of instrumentallyrecorded earthquakes with $\mathrm{Mw} \geq 8$ (Newcomb and McCann 1987) in comparison to Sumatra Subduction Zone which has generated an Mw 9.4 2004 Aceh Earthquake. This can be explained by the extent of seismogenic zone in these two regions where Java Subduction has narrower seismogenic zone than Sumatra Subduction (e.g., Kopp et al. 2002; Kopp et al. 2009; Dessa et al. 2009; Klingelhoefer et al. 2010; Krabbenhoeft et al. 2010; Planert et al. 2010; Shulgin et al. 2011; Widiyantoro et al. 2011).

\section{METHODS}

This study is based on observations of publicly available datasets to identify geomorphic features, subsurface structures, and their relations to seismicity along the Java Subduction Zone. The Indonesian bathymetric data (BATNAS) (http://tides.big.go.id/DEMNAS/index.html) with six arc-second spatial resolution were analyzed and interpreted to understand the seafloor morphology and its relations to residual bathymetry anomalies. BATNAS was compiled from gravity anomaly inversion resulting from altimetry data inversion, with additional data from various sources (BIG, NGDC, BODC, BPPT, LIPI, P3GL and other agencies) using single or multibeam surveys. Residual bathymetry data (from Bassett and Watts, 2015) were used to identify the anomalies or the structural highs on the lower plate, which were determined based on a cut-off value of $0 \mathrm{~m}$. This value marks the extent of seamounts and ridge on the oceanic crust and the landward extent of the forearc basin. Residual bathymetry data were generated from Gridded Bathymetry Data (GEBCO) by subtracting the average trench-normal profile so that bathymetric anomalies, which represent subducting plate structures, can be resolved. We also utilized the earthquake hypocentres from ISC-EHB Bulletin (http://www.isc.ac.uk), covering a period of 1976 - 2015 and focal mechanism solutions of the Global Centroid-Moment Tensor (GCMT) (https://www.globalcmt.org). The hypocentres were relocated based on EHB Procedures which was described in Engdahl et al. (1998) while the fault plane solutions were determined based on the methodology in Dziewonski et al. (1981) and Ekström et al. (2012). Both datasets were examined to show the dynamic of earthquakes in the research area. The criterion for plotting in this paper was magnitude greater than or equal to 4.5 and depth less than or equal to $50 \mathrm{~km}$. Earthquake foci were subdivided into three main categories as suggested by Hauksson (1990); thrust faults are those with rakes of $45^{\circ}$ to $135^{\circ}$, normal faults are those with rakes of $-45^{\circ}$ and $-135^{\circ}$, and strike-slip faults are those with rakes of $44^{\circ}$ to $-44^{\circ}$ and $136^{\circ}$ and $224^{\circ}$. Along with seismicity, subducting plate geometry SLAB 1.0 (Hayes et al. 2012) was displayed to compare the top lower plate to hypocentres and earthquake activities. The interpretations based on previous datasets are discussed with some published seismic interpretation profiles (i.e., Kopp et al. 2009; Lüschen et al. 2011).

\section{RESULTS}

The study area elongates $1800 \mathrm{~km}$ in the south of Java and Lesser Sunda and trend in the E-W direction. Thus, the research area was divided into three divisions: (A) Western Area, (B) Central Area, and (C) Eastern Area. 

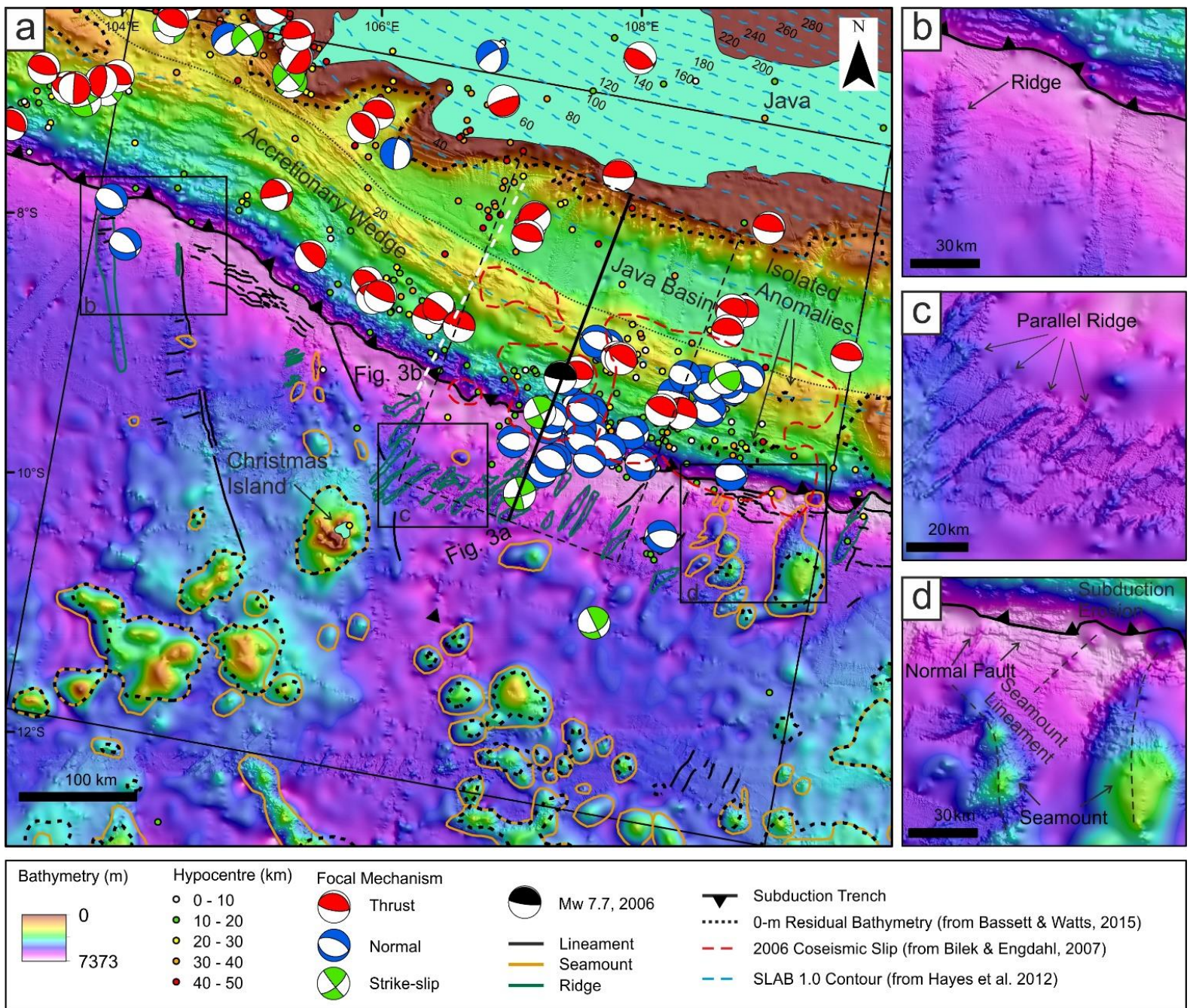

Figure 2. a) Bathymetric map of the western area with structural interpretation, compiled with seismicity and extent of coseismic slip of Mw 7.7 2006 Earthquake. b) N-S oriented ridge near subduction trench. c) Series of parallel ridges on oceanic crust. d). Seamounts which associated with the landward progression of the trench.

\section{Western Area}

The western part of Java Subduction Zone is characterized by the NW-SE trending trench (Figure 2a). The maximum depth of the trench reaches $6900 \mathrm{~m}$. The accretionary wedge is about $120 \mathrm{~km}$ in width and associated with trenchparallel ridges. Between the accretionary wedge and Java, the forearc basin is narrowing to the west, and it disappears in the south of the western end of Java. Normal faults can be traced on oceanic crust along the subduction trench. South of the trench, many seamounts are observed in the oceanic crust with width up to $128 \mathrm{~km}$. Seamounts can emerge till $6000 \mathrm{~m}$ from adjacent seafloor in which was exposed above sea level, forming
Christmas Island. Close to the western trench, a single N-S trending ridge is cut by $\mathrm{E}-\mathrm{W}$ lineaments (Figure 2b). Series of Parallel Ridge, slightly elevated about $600 \mathrm{~m}$ from surrounding bathymetry and trending NE-SW, are found in the northwest of Christmas Island (Figure 2c). In the eastern part, some small seamounts are converging with the accretionary wedge in the trench (Figure 2d). The trench is progressed landward about $7 \mathrm{~km}$, which is comparable to the size of approaching seamounts. It is also shown that the seamounts are faulted by E-W normal faults. There are three residual bathymetry anomalies that overprint the accretionary wedge area, and they are located within the coseismic slip extent of the 2006 earthquake. These anomalies 
are interpreted as subducting seamount beneath wedge and possibly associated with seamount in further seaward.

Seismicity in the western area is mainly concentrated in the east, area of Mw 7.72006 Earthquake, and fairly distributed along with accretionary wedge (Figure 2a). Seismicity in the accretionary wedge area mainly has a shallow depth, less than $30 \mathrm{~km}$. Deeper hypocentres are observed within the forearc basin. Several earthquakes are found in the oceanic crust with depth less than $20 \mathrm{~km}$. Thrust fault solutions are the most common and distributed in the trench, accretionary wedge, and forearc basin. Normal faulting activities are majorly observed in the area of 2006 Earthquake rupture, both in the accretionary wedge and near-trench oceanic crust. Two normal fault solutions are associated with a ridge in the western end. Strike-slip fault solutions are limited in the west of Java and oceanic floor, south of trench.

The largest thrust fault event is Mw 7.72006 Earthquake with depth of $29 \mathrm{~km}$ (Figure 3a), suggesting that this earthquake is located in oceanic mantle but we prefer the result from that located the hypocentre at a depth of $20 \mathrm{~km}$ (USGS;
GCMT; Pesicek et al. 2010) as it has generated tsunami around south of West Java. Some thrust faults are also found beneath the top of the subducting plate, and there are three earthquakes which attributed to the megathrust earthquake (Figure 3a). Based on seismic interpretation from Kopp et al. (2009), splay faults in accretionary wedge may contribute to earthquakes occurrence in the accretionary wedge, above the top of the subducting plate (Figure 3a and 3b). Normal fault events mainly took place in oceanic crust, up-dip from the hypocentre of Mw 7.7 2006 earthquake. Anomalously, several normal fault activities are located close to plate interface and are plausibly related to local deformation due to subducting ridges on top of oceanic crust. These ridges were previously interpreted as seamount by Kopp et al. (2009), but we consider as ridge as it has relatively small geometry (Figure 3b), and it might be similar to series of parallel ridge further seaward (Figure 2a). Strike-slip fault earthquakes in the northwest part of the area are considered as a result of deformation at the southern tip of Sumatran Fault. Strike-slip faulting activities are also observed in the oceanic crust (Figure 3a).

\section{Central Area}
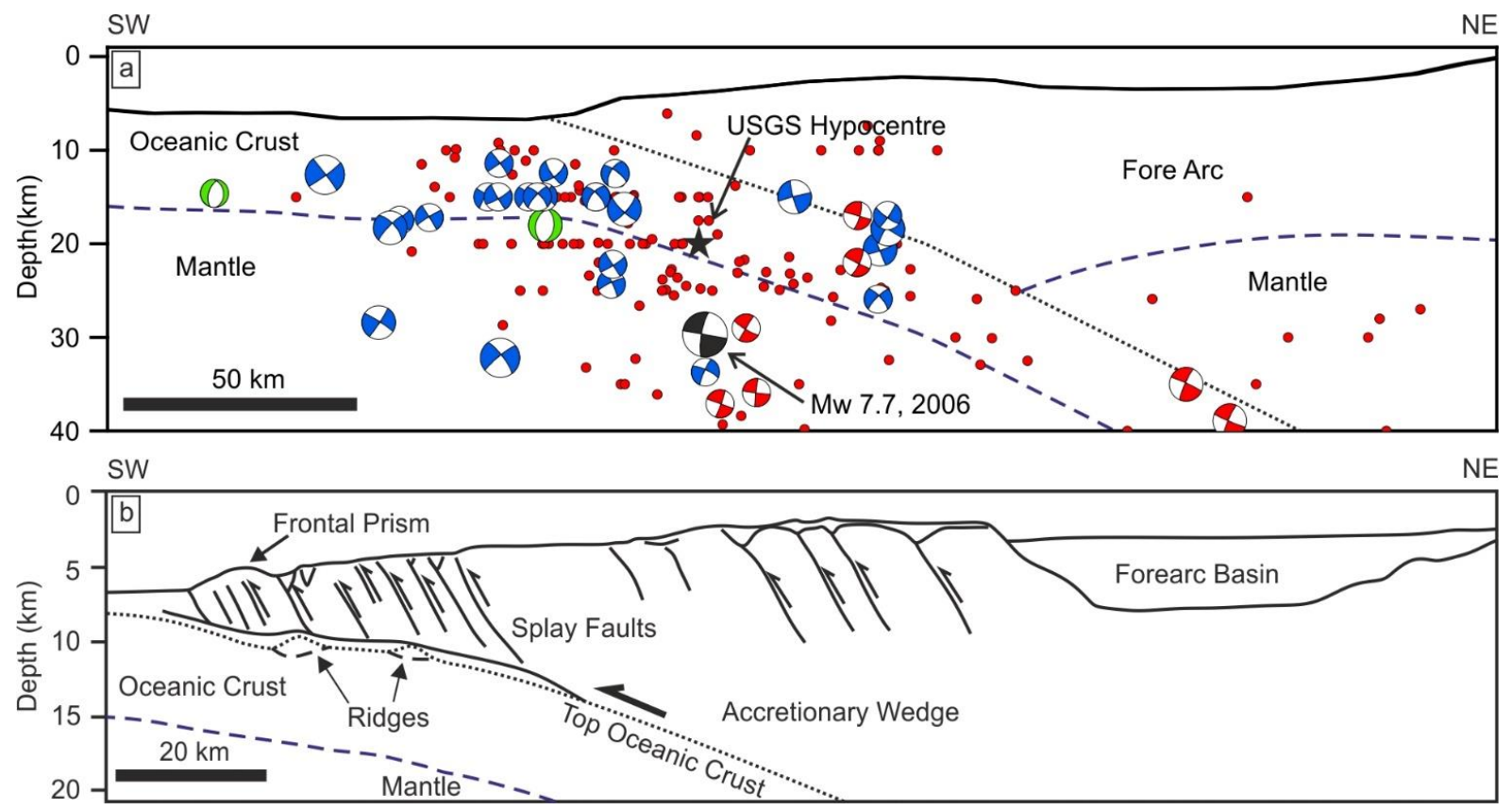

Figure 3. a) Cross-section showing seismicity and focal mechanism within a zone of $100 \mathrm{~km}$ width from the centerline in the Western Area. Mantle-crust boundary is adapted from Kopp 2009. Top of subducting geometry based on SLAB 1.0 (Hayes et al. 2012). b) Seismic Interpretation Profile SO137-03 (modified after Kopp et al., 2009). 
In Central Area, the depth of the trench goes shallower towards east from about $7100 \mathrm{~m}$ to 6200 $\mathrm{m}$ in WNW-ESE direction (Figure 4a). Accretionary wedge orientation is deflected further landward, and it coincides with narrower forearc basin, comparing to the Western Area. A large oceanic feature, Roo Rise, which elevated up to $3500 \mathrm{~m}$ from seafloor occupies most of the oceanic crust in the south of the subduction trench. There are five residual bathymetry anomalies, which are incorporated to the uplifted zone within the accretionary wedge. The westernmost residual bathymetry high is located further north from the deepest trench, which is progressed about $20 \mathrm{~km}$ landward (Figure $4 \mathrm{a}$ and $4 \mathrm{~b}$ ). Two ridges are subducted beneath the accretionary wedge in this part of the trench (Figure 4b). Further to the central part, a seamount bends the trench and is situated just south of uplifted seafloor with residual bathymetry anomalies (Figure $4 \mathrm{c}$ ). This indicates that a seamount might be lies underneath this uplifted seafloor. The existence of large

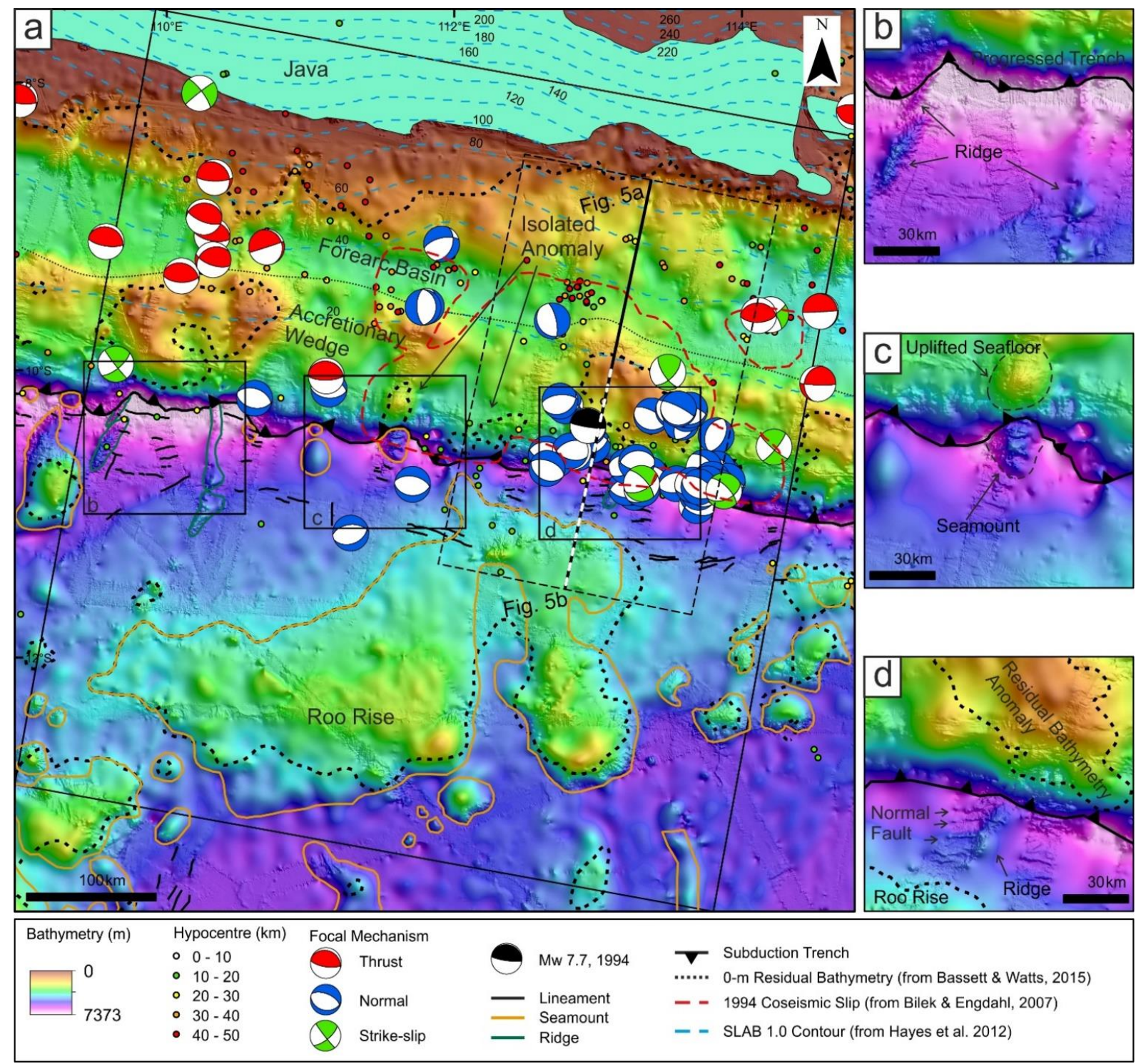

Figure 4. a) Bathymetric map of the Central Area with structural interpretation, compiled with seismicity and extent of coseismic slip of Mw 7.8 1998 Earthquake. b) NNE-SSW oriented ridge near subduction trench, associated with the landward progression of the trench. c) Seamount is in contact with the trench and uplifted seafloor in front of the seamount. d). Uplifted zone with high residual bathymetry is in further landward from Roo Rise. 
residual bathymetry high in uplifted seafloor in the accretionary wedge may indicate that part of Roo Rise has been subducted (Figure 4d). This large residual bathymetry is included within the coseismic slip extent of the 1994 earthquake.

The earthquake activities of the Central Area are shown in Figure 4a. The accretionary wedge is not dominated by thrust faulting event. An area with large residual bathymetry anomaly within accretionary wedge in the west has only two earthquake activities, while another large residual bathymetry high in the east which is included within coseismic slip extent of Mw 7.81994 Earthquake dominated by normal faulting activities with several strike-slip faulting at the edge of deformation extent. Most of the deep seismicity $(30-50 \mathrm{~km})$ is located beneath the forearc basin with thrust fault solutions in the north of the west residual bathymetry anomaly and in the east end forearc basin. Oceanic crust is a relatively aseismic area, and few earthquakes in which with normal fault solutions mainly occurred close to the trench.

The Mw 7.81994 earthquake is a significant earthquake in the central area. It has a depth of $35.5 \mathrm{~km}$ but, based on USGS, the depth of this earthquake hypocentre is about $18 \mathrm{~km}$ (Figure 5a). The depth from USGS seems realistic since this earthquake is associated with the tsunami in the south of East Java. A number of seismicities are observed on top of the subducting plate, but most solutions are the normal fault.

Based on seismic interpretation profile from Lüschen et al. (2011), a set of normal faults which offsets a strong key reflector on upper part oceanic crust might be related normal fault activities at the trench and high subducting relief underneath accretionary wedge are possibly subductingseamount, indicating that part of Roo Rise has been subducted (Figure 5b). Although the seismic reflection profile shows that thrust faults dominate in the accretionary wedge, it is also found a normal fault solution with an oblique-totrench orientation, suggesting that local extensional deformation has happened within the accretionary wedge.

\section{Eastern Area}

Eastern Area consists of E-W oriented subduction trench where it connected to the deformation front of Banda Subduction, Timor trough, which is deflected seaward about $120 \mathrm{~km}$. The trench possesses depth reaching $7000 \mathrm{~m}$. Morphology of accretionary wedge is characterized by uplifted region in the west, and then it changes, becoming two trench-parallel ridges, and these ridges disappear further east with the eastward deepening trend. Forearc Basin, which known as Lombok

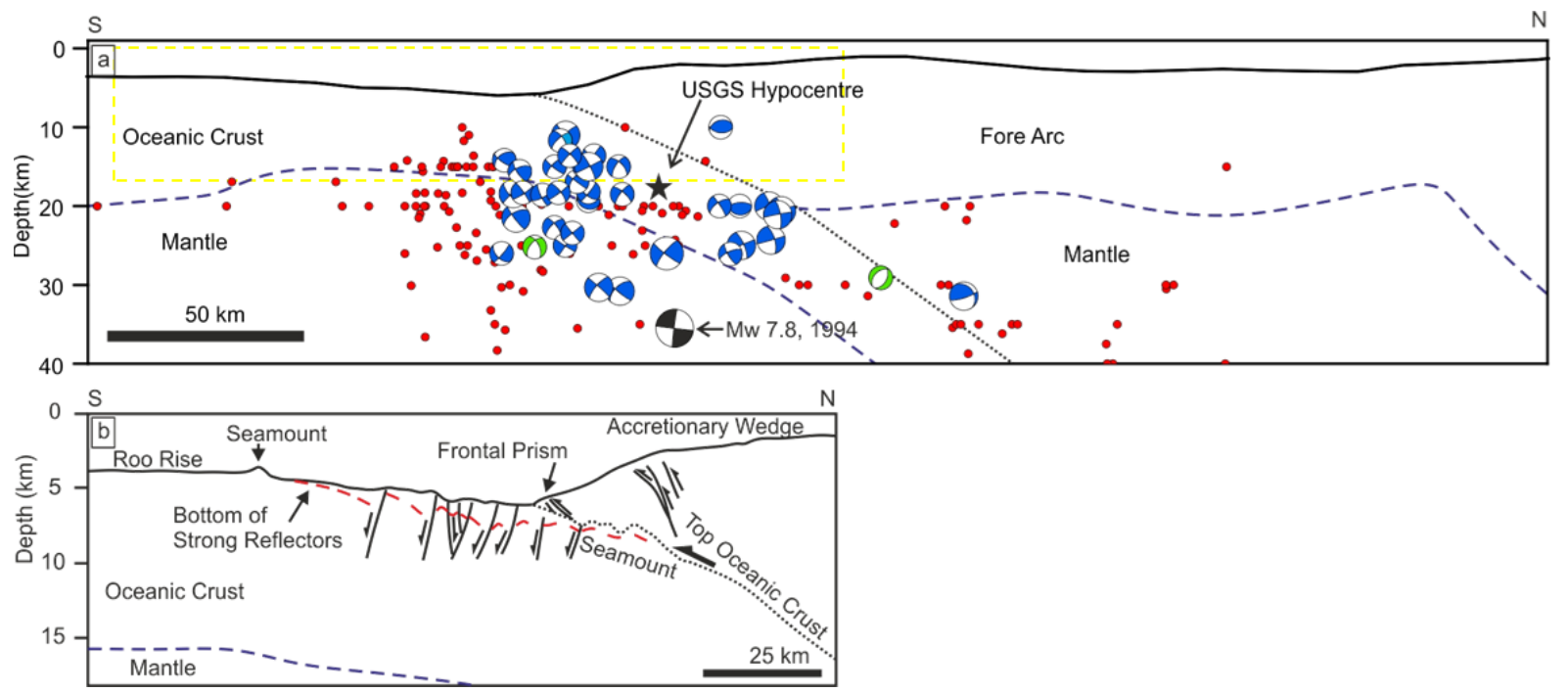

Figure 5. a) Cross-section showing seismicity and focal mechanism within a zone of $100 \mathrm{~km}$ width from the centerline in the Central Area. Mantle-crust boundary is adapted from Luschen 2009. Top of subducting geometry based on SLAB 1.0 (Hayes et al. 2012). The yellow rectangle indicates the approximate boundary of figure 5b. b) Seismic Interpretation Profile BGR06305 (modified after Lüschen et al., 2011). 




Figure 6. a) Bathymetric map of the Eastern Area with structural interpretation, compiled with seismicity and extent of coseismic slip of Mw 8.31977 Earthquake. b) Comparable residual bathymetry highs on both oceanic crust and accretionary wedge. c) Ridge on Oceanic crust. d). Isolated residual bathymetry anomalies in accretionary wedge and normal faults in the near trench zone.

Basin, is narrowing eastward and bounded by Sumba in the east. Argo Abyssal Plain is a relatively low relief oceanic crust, comparing to the oceanic floor in western and central areas. Seamounts which indicated by uplifted seafloor and residual bathymetry anomalies are found in the east, which in line with residual bathymetry anomaly further landward within accretionary wedge (Figure 6b). Several ridges are oblique to trench in the central part, and there is no observable structural high further east (Figure 6c). However, there are two residual bathymetry anomalies observed in the eastern part of the accretionary wedge (Figure 6d). Normal faults are common structures in the near trench area.
In general, earthquake activities in the Eastern Area are mainly located in the near trench zone and forearc basin (Figure 6a). Further seaward of the trench, Argo Abyssal Plain is a relatively aseismic zone. Seismic activities in the forearc basin are more intensive in the east with a depth of $10-50 \mathrm{~km}$. Thrust fault solutions dominate the basin, and many of the activities are located in the west of Sumba and south of Sumbawa. The accretionary wedge is characterized by the absence of thrust fault activity. In the western part, there are deep seismicities $(30-50 \mathrm{~km})$ located at the side of a residual bathymetry anomaly. Normal faults are the most common solutions in the near trench area and more concentrated in the eastern 
part, although only one strike-slip faulting is found close to the trench.

Seismicity is mainly observed below the mantlecrust boundary in both oceanic plate and forearc areas (Figure 7a). A normal fault is also responsible for the largest earthquake in the region in 1977 with $\mathrm{Mw} 8.3$ and a depth of $25 \mathrm{~km}$. This is an intra-slab earthquake located within the mantle. Further landward, it can be observed that many thrust fault solutions might be related to plate interface deformation. According to previous interpretation from Lüschen et al. (2011), a number of normal faults are shown dominated the near trench area and a large thrust fault breaks the entire oceanic crust beneath the accretionary wedge which we prefer to consider as normal fault (figure 7b) and might be associated by two isolated residual bathymetry anomalies in west of seismic reflection line.

\section{DISCUSSION}

Morphology along the Java subduction zone is laterally varying. The oceanic floor in the seaward subduction trench consists of features such as normal faults, ridges, seamounts, and Roo Rise. Normal faults that dominate the near trench area are interpreted as a result of plate-bending deformation. Some subducting seamount beneath the accretionary wedge as indicated by residual bathymetry anomalies are considered as a continuation of a series of seamount on oceanic floor. Residual bathymetry anomaly highs in the eastern area also reflect the uplifted part of oceanic crust, which is broken by a large normal fault. The depth and orientation of the subduction trench may vary in response to the incoming oceanic crust features. The deepest part of the trench is subject of tectonic erosion where the trench is progressed northward (Kopp et al. 2006), and it is associated with large subducting features beneath accretionary wedge as indicated by the uplifted accretionary wedge in front of trench and a residual bathymetry anomaly. Some subducting seamounts are in contact with a trench ond have subducted beneath accretionary wedge, creating landward deflection of the trench. South of West Java, the accretionary wedge is characterized by a series of parallel ridges, and the forearc basin is relatively flat. The central part of the accretionary
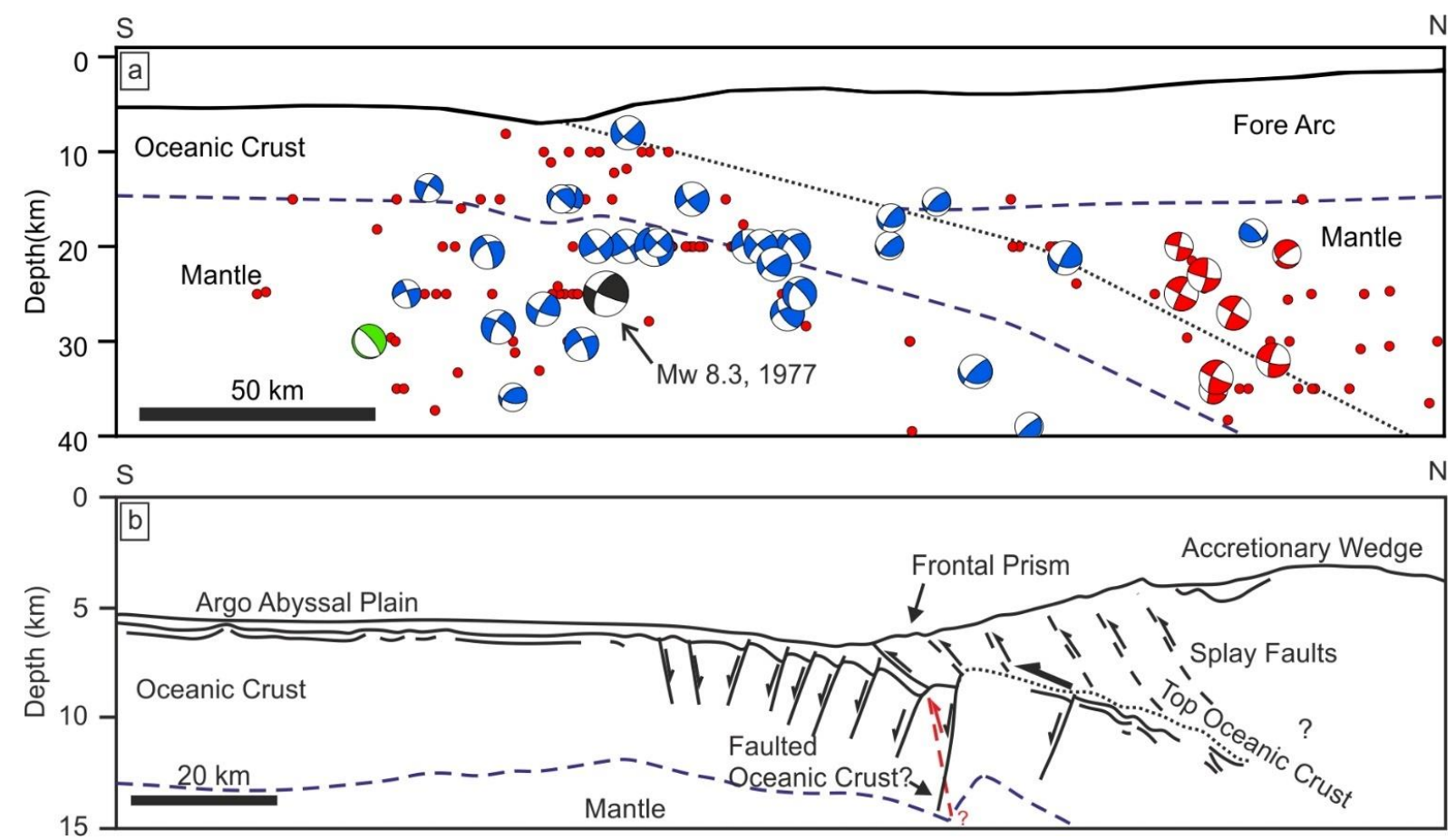

Figure 7. a) Cross-section showing seismicity and focal mechanism within a zone of $100 \mathrm{~km}$ width from the centerline in the Eastern Area. Mantle-crust boundary is adapted from Luschen 2009. Top of subducting geometry based on SLAB 1.0 (Hayes et al. 2012). b) Seismic Interpretation Profile BGR06-311 (modified after Lüschen et al. 2011). 
wedge is marked by an abrupt change in morphology and is slightly deflected landward. It was also accompanied by narrowing and shallowing forearc basin which highly deformed. Many thrust faults are observed beneath the forearc basin in the south of East Java and fold entire basin strata (Nugraha and Hall 2012). To the east, the Lombok Basin is relatively flat and deeper than Java Basin, and it is bounded by Sumba in the east. Horst and Graben structures are observed in the basement, while the filling sediments are less deformed (Lüschen et al. 2011). The accretionary wedge in seaward of Lombok Basin consists of two parallel ridges and narrower to the east. Changes in shape and orientation of the accretionary wedge and forearc basin indicate the existence of subducting oceanic features beneath. The central part of accretionary wedge and forearc basin where the regions are highly disrupted is situated close to Roo Rise and seamounts, while the approaching features in the western area are majorly oceanic ridge and the eastern area is relatively associated with low relief oceanic seafloor.

Seismogenic zone in Java Subduction Zone which expected to be source of megathrust earthquake is marked by seaward slope break of accretionary wedge and seaward limit of forearc basin (Krabbenhoeft et al. 2010), but earthquake activity within the seismogenic zone is characterized by lack of thrust fault activity and the large thrust fault earthquakes in 1994 and 2006 which located beneath accretionary wedge at a depth of $18 \mathrm{~km}$ and $20 \mathrm{~km}$, respectively, located within the subducting oceanic crust. However, considering the slab geometry, we argue that both earthquakes have slipped along shallower depth about $12 \mathrm{~km}$. Additionally, our observations suggest that most thrust fault earthquakes associated with deformation on plate interface are majorly located beneath the forearc basin in Western and Eastern Areas. It is also noted that the thrust fault activity beneath the accretionary wedge is absence in the Eastern Area. Some normal faults took place in the plate interface, which can be local deformation because of structural highs on top of the subducting plate and occurred at the edge of structural highs. The existence of these features on top of oceanic crust lead local extensional deformation (Dominguez et al. 1998; Dominguez et al. 2000), and earthquakes have mainly happened at the edge of subducting features.
The two large thrust fault earthquakes in 1994 and 2006 are a result of megathrust deformations. Both earthquakes were considered as tsunami earthquakes and ruptured along with plate interface with shallow dipping fault plane (Abercrombie et al. 2001; Kato et al. 2007; Bilek and Engdahl 2007). It is also noted that these earthquakes are unusually characterized by long rupture durations and low rupture velocity (Abercrombie et al. 2001; Kato et al. 2007; Bilek and Engdahl 2007). Raharja et al. (2016), based on GPS modeling, added that the 2006 Earthquake has ruptured in the region, which has low rigidity and tends to slip for long time periods continuously. The Mw 7.81994 Earthquake possibly has occurred in a similar region as it comprises identic characteristics. Hence, we argue that both earthquakes are interpreted to be nucleated on soft or unconsolidated sediment above the incoming plate. The 1994 earthquake caused a larger tsunami run-up than the 2006 earthquake as it slipped over a large subducting seamount (Abercrombie et al. 2001) or an oceanic plateau (Bassett and Watts 2015) on top of subducting plate which more favor to generate tsunami (Geersen 2019). They were then mainly followed by up-dip normal fault seismicities, and this suggests that stress was transferred from deeper to the shallower part of oceanic crust and reactivate normal faults.

Plate bending is also responsible for deforming near the trench area and creating normal faults. This deformation has contributed as the most intensives source of earthquakes along Java Subduction. Moreover, in the eastern part, a broken oceanic crust beneath the accretionary wedge is faulted by the largest bending normal fault in the Java Subduction Zone. According to Lynnes and Lay (1988), the ruptured zone of Mw 8.3 1977 Earthquake has extended to about 30-50 $\mathrm{km}$ depth. Thus we consider that this earthquake may slip along the crustal-scale normal fault. The existence of this large normal fault can be related to the geometry of the subducting plate, where it becomes vertical at a depth of $400 \mathrm{~km}$ beneath Flores (Widiyantoro et al. 2011). The vertical geometry may contribute to a larger amount of slab pull and lead to subduction roll-back and might be responsible for the eastward increase of convergence velocity. 


\section{CONCLUSIONS}

We have presented evaluations of lower and upper plate structures in reference to their earthquake activities. Features such as normal faults, ridges, and seamounts which lie on oceanic crust can also exist on subducting oceanic plate beneath accretionary wedge. Their presence can be deducted based on morphology, residual bathymetry anomalies, and seismic reflection data. They influence the earthquake activities which occurred in the subduction zone. Seismicity along Java Subduction Zone is mainly concentrated in the near trench area and secondly in the forearc basin area, while oceanic floor area relatively has a low level of seismicity. Although Java Subduction Zone is resulting from the convergence between Oceanic Australian Plate and Eurasia, much observable fault solutions are normal faults which located beneath accretionary wedge and associated with plate-bending deformation. Thrust faulting activity is mainly found beneath the forearc basin that related to plate interface deformation, but two significant thrust faulting activities are now considered as intra-slab deformation of the lower plate. Several strike-slip fault solutions can be present in convergence regime and are mainly located within the lower plate.

\section{REFERENCES}

Abercrombie RE, Antolik M, Felzer K, Ekström G (2001) The 1994 Java tsunami earthquake: Slip over a subducting seamount. Journal of Geophysical Research: Solid Earth 106:6595-6607. doi: 10.1029/2000JB900403

Bassett D, Watts AB (2015) Gravity anomalies, crustal structure, and seismicity at subduction zones: 1 . Seafloor roughness and subducting relief. Geochemistry, Geophysics, Geosystems 16:15081540. doi: 10.1002/2014GC005684

Bilek SL, Engdahl ER (2007) Rupture characterization and aftershock relocations for the 1994 and 2006 tsunami earthquakes in the Java subduction zone. Geophysical Research Letters 34:1-5. doi: 10.1029/2007GL031357
Chauhan APS, Singh SC, Hananto ND, Carton H, Klingelhoefer F, Dessa J-X, Permana H, White NJ, Graindorge D, Team SS (2009) Seismic imaging of forearc backthrusts at northern Sumatra subduction zone. Geophysical Journal International 179:1772-1780. doi: 10.1111/j.1365-246X.2009.04378.x

Daryono MR, Natawidjaja DH, Sieh K (2012) Twin - Surface Ruptures of the March 2007 M\&gt;6 Earthquake Doublet on the Sumatran FaultTwin - Surface Ruptures of the March 2007 M\&gt;6 Earthquake Doublet on the Sumatran Fault. Bulletin of the Seismological Society of America 102:2356-2367. doi: $10.1785 / 0120110220$

DeMets C, Gordon RG, Argus DF (2010) Geologically current plate motions. Geophysical Journal International 181:1-80. doi: 10.1111/j.1365246X.2009.04491.x

Dessa J-X, Klingelhoefer F, Graindorge D, André C, Permana H, Gutscher M-A, Chauhan A, Singh SC, Team the S-OS (2009) Megathrust earthquakes can nucleate in the forearc mantle: Evidence from the 2004 Sumatra event. Geology 37:659662. doi: 10.1130/G25653A.1

Dominguez S, Lallemand SE, Malavieille J, Von Huene R (1998) Upper plate deformation associated with seamount subduction. Tectonophysics 293:207224 doi: 10.1016/S00401951(98)00086-9

Dominguez S, Malavieille J, Lallemand SE (2000) Deformation of accretionary wedges in response to seamount subduction: Insights from sandbox experiments. Tectonics 19:182-196. doi: 10.1029/1999TC900055

Fritz HM, Kongko W, Moore A, McAdoo B, Goff J, Harbitz C, Uslu B, Kalligeris N, Suteja D, Kalsum K, Titov V, Gusman A, Latief H, Santoso E, Sujoko S, Djulkarnaen D, Sunendar H, Synolakis C (2007) Extreme runup from the 17 July 2006 Java tsunami. Geophysical 
Research Letters 34:1-5. doi: 10.1029/2007GL029404

Geersen J (2019) Sediment-starved trenches and rough subducting plates are conducive to tsunami earthquakes. Tectonophysics 762:28-44. doi: https://doi.org/10.1016/j.tecto.2019.04. 024

Hall R (2012) Late Jurassic-Cenozoic reconstructions of the Indonesian region and the Indian Ocean. Tectonophysics 570-571:1-41.

doi:

10.1016/j.tecto.2012.04.021

Hamilton W (1979) Tectonics of the Indonesian Region. USGS Professional Paper. United States Printing Office, Washington

Hauksson E (1990) Earthquakes, faulting, and stress in the Los Angeles Basin. Journal of Geophysical Research: Solid Earth 95:15365-15394.

doi: 10.1029/JB095iB10p15365

Hayes GP, Wald DJ, Johnson RL (2012) Slab1.0: A three-dimensional model of global subduction zone geometries. Journal of Geophysical Research: Solid Earth 117. doi: 10.1029/2011JB008524

Heine C, Muller D, Gaina C (2004) Reconstructing the Lost Eastern Tethys Ocean Basin: Convergence History of the SE Asian Margin and Marine Gateways. In: Clift P, Kuhnt W, Wang P, Hayes D (eds) Continent - Ocean Interactions Within East Asian Marginal Seas. Geophysical Monograph Series, Washington, pp 37-54

Henstock TJ, McNeill LC, Bull JM, Cook BJ, Gulick SPS, Austin JA, Permana H, Djajadihardja YS (2016) Downgoing plate topography stopped rupture in the A.D. 2005 Sumatra earthquake. Geology 44:71-74. doi: 10.1130/G37258.1

Henstock TJ, McNeill LC, Tappin DR (2006) Seafloor morphology of the Sumatran subduction zone: Surface rupture during megathrust earthquakes? Geology 34:485-488. doi: 10.1130/22426.1
Kato T, Ito T, Abidin HZ, Agustan (2007) Preliminary report on crustal deformation surveys and tsunami measurements caused by the July 17 , 2006 South off Java Island Earthquake and Tsunami, Indonesia. Earth, Planets and Space 59:1055-1059. doi: 10.1186/BF03352046

Klingelhoefer F, Gutscher MA, Ladage S, Dessa JX, Graindorge D, Franke D, Andre C, Permana H, Yudistira T, Chauhan A (2010) Limits of the seismogenic zone in the epicentral region of the 26 December 2004 great Sumatra-Andaman earthquake: results from seismic refraction and wide-angle reflection surveys and thermal modeling. Journal of Geophysical Research 115:B01304. doi: 10.1029/2009JB006569

Kopp H, Flueh ER, Petersen CJ, Weinrebe W, Wittwer A, Scientists M (2006) The Java margin revisited: Evidence for subduction erosion off Java. Earth and Planetary Science Letters 242:130-142. doi: 10.1016/j.epsl.2005.11.036

Kopp H, Hindle D, Klaeschen D, Oncken O, Reichert C, Scholl D (2009) Anatomy of the western Java plate interface from depth-migrated seismic images. Earth and Planetary Science Letters 288:399407. doi: 10.1016/j.eps1.2009.09.043

Kopp H, Klaeschen D, Flueh ER, Bialas J (2002) Crustal structure of the Java margin from seismic wide-angle and multichannel reflection data. Journal of Geophysical Research 107:1-24

Kopp H, Kukowski N (2003) Backstop geometry and accretionary mechanics of the Sunda margin. Tectonics 22. doi: 10.1029/2002TC001420

Krabbenhoeft A, Weinrebe RW, Kopp H, Flueh ER, Ladage S, Papenberg C, Planert L (2010) Bathymetry of the Indonesian Sunda margin-relating morphological features of the upper plate slopes to the location and extent of the seismogenic zone. Natural hazards and Earth System Sciences 10:1899-1911. doi: 10.5194/nhess-10-1899-2010 
Lüschen E, Müller C, Kopp H, Engels M, Lutz R, Planert L, Shulgin A, Djajadihardja YS (2011) Structure, evolution and tectonic activity of the eastern Sunda forearc, Indonesia, from marine seismic investigations. Tectonophysics 508:621. doi: 10.1016/j.tecto.2010.06.008

Lynnes CS, Lay T (1988) Source Process of the Great 1977 Sumba Earthquake. Journal of Geophysical Research: Solid Earth 93:13407-13420.

doi: 10.1029/JB093iB11p13407

Malod JA, Karta K, Beslier MO, Zen MT (1995) From normal to oblique subduction: Tectonic relationships between Java and Sumatra. Journal of Southeast Asian Earth Sciences 12:85-93. doi: 10.1016/0743-9547(95)00023-2

Masson DG, Parson LM, Milsom J, Nichols G, Sikumbang N, Dwiyanto B, Kallagher H (1990) Subduction of seamounts at the Java Trench: a view with long-range sidescan sonar. Tectonophysics 185:5165. doi: 10.1016/0040-1951(90)90404$\mathrm{V}$

McCaffrey R (2009) The Tectonic Framework of the Sumatran Subduction Zone. Annual Review of Earth and Planetary Sciences 37:345-366. doi: 10.1146/annurev.earth.031208.100212

Mukti MM, Singh SC, Deighton I, Hananto ND, Moeremans R, Permana H (2012) Structural evolution of backthrusting in the Mentawai Fault Zone, offshore Sumatran forearc. Geochemistry, Geophysics, Geosystems 13:1-21. doi: 10.1029/2012GC004199

Natawidjaja DH, Triyoso W (2007) the Sumatran Fault Zone - From Source To Hazard. Journal of Earthquake and Tsunami $01: 21-47$.

doi: $10.1142 / \mathrm{S} 1793431107000031$

Newcomb K, McCann W (1987) Seismic History and Seismotectonics of the Sunda Arc. Journal of Geophysical Research 92:421-439. doi: 10.1029/JB092iB01p00421

Nugraha AMS, Hall R (2012) CENOZOIC HISTORY OF THE EAST JAVA
FOREARC. In: Proceedings Indonesian Petroleum Association, 36th Annual Conventionh Annual Convention, INDONESIAN PETROLEUM ASSOCIATION Thirty-Sixth Annual Convention \& Exhibition, May 2012. pp IPA12-G-028

Pesicek JD, Thurber CH, Zhang H, Deshon HR, Engdahl ER, Widiyantoro S (2010) Teleseismic double-difference relocation of earthquakes along the Sumatra-Andaman subduction zone using a 3-D model. Journal of Geophysical Research: Solid Earth 115:1-20. doi: 10.1029/2010JB007443

Planert L, Kopp H, Lueschen E, Mueller C, Flueh ER, Shulgin A, Djajadihardja Y, Krabbenhoeft A (2010) Lower plate structure and upper plate deformational segmentation at the Sunda - Banda arc transition, Indonesia. Journal of Geophysical Research 115:B08107. doi: 10.1029/2009JB006713

Raharja R, Gunawan E, Meilano I, Abidin HZ, Efendi J (2016) Long aseismic slip duration of the 2006 Java tsunami earthquake based on GPS data. Earthquake Science 29:291-298. doi: 10.1007/s11589-016-0167-y

Shulgin A, Kopp H, Mueller C, Planert L, Lueschen E, Flueh ER, Djajadihardja Y (2011) Structural architecture of oceanic plateau subduction offshore Eastern Java and the potential implications for geohazards. Geophysical Journal International 184:12-28. doi: 10.1111/j.1365-246X.2010.04834.X

Sieh K, Natawidjaja D (2000) Neotectonics of the Sumatran fault, Indonesia. Journal of Geophysical Research: Solid Earth 105:28295-28326. doi: 10.1029/2000JB900120

Simons WJF, Socquet A, Vigny C, Ambrosius BAC, Abu SH, Promthong C, Subarya C, Sarsito DA, Matheussen S, Morgan P, Spakman W (2007) A decade of GPS in Southeast Asia: Resolving Sundaland motion and boundaries. Journal of Geophysical Research: Solid Earth 
112:B003868.

doi:

10.1029/2005JB003868

Singh SC, Carton H, Tapponnier P, Hananto ND, Chauhan APS, Hartoyo D, Bayly M, Moeljopranoto S, Bunting T, Christie P, Lubis H, Martin J (2008) Seismic evidence for broken oceanic crust in the 2004 Sumatra earthquake epicentral region. Nature Geoscience 1:777-781. doi: 10.1038/ngeo336

Singh SC, Hananto N, Mukti M, Robinson DP, Das S, Chauhan A, Carton H, Gratacos B, Midnet S, Djajadihardja Y, Harjono H (2011) Aseismic zone and earthquake segmentation associated with a deep subducted seamount inSumatra. Nature Geoscience 4:308-311. doi: 10.1038/ngeo1119

Susilohadi S, Gaedicke C, Ehrhardt A (2005) Neogene structures and sedimentation history along the Sunda forearc basins off southwest Sumatra and southwest Java. Marine Geology 219:133-154. doi: 10.1016/j.margeo.2005.05.001

Tsuji Y, Imamura F, Matsutomi H, Synolakis CE, Nanang PT, Jumadi, Harada S, Han SS, Arai K, Cook B (1995) Field survey of the East Java earthquake and tsunami of June 3, 1994. Pure and Applied Geophysics 144:839-854. doi: 10.1007/BF00874397

Widiyantoro S, Pesicek JD, Thurber CH (2011) Subducting slab structure below the eastern Sunda arc inferred from nonlinear seismic tomographic imaging. In: Hall R, Cottam MA, Wilson MEJ (eds) The SE Asian Gateway: History and Tectonics of the Australia-Asia Collision, 355th edn. Geological Society of London, London, pp 139-15 
